\title{
Border: The Videographic Traces by Laura Waddington as a Cinematographic Memorial
}

\author{
EvA KuHN
}

A shadowy figure huddles in front of a dark ground, surrounded by high, billowing grass. The sky is crimson and a light is glaring from the horizon. Now the figure stirs - a bright hooded sweatshirt can be made out. The camera is close; it kneels with the figure in the field and films as it stalks onward and ducks down again-now it can no longer be seen. Alone, the camera films wind and grass and the constant white light. The image becomes grainier and wavers. This place seems oddly dematerialized, disembodied, as in a dream or memory. A small black silhouette rises up, becomes visible against the light on the horizon, and again dissolves into the glimmering dots of the image noise. The camera, working hard with hardly any light, seems to reach its limit. A pan to the left makes the image into a painterly blur of crimson, gray, and brown tones.

\section{Figure 1}

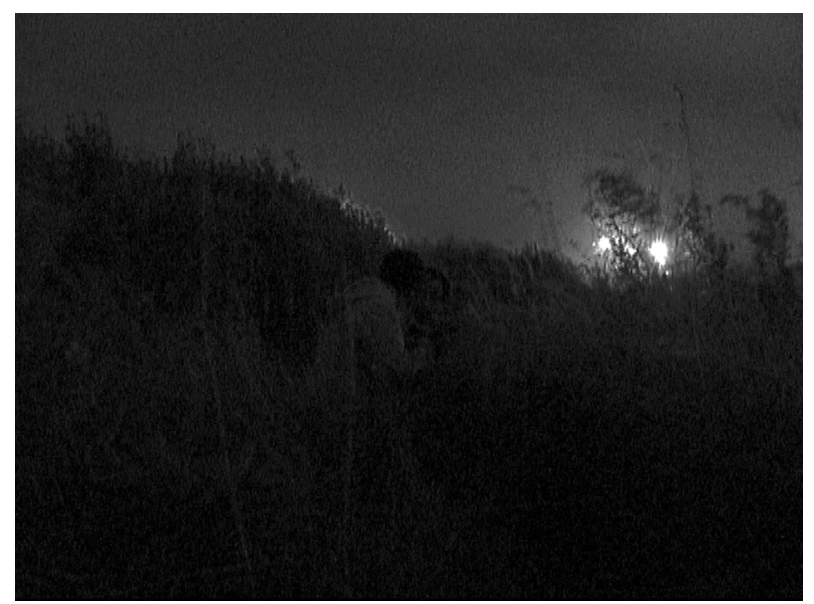


The documentary video essay Border takes place in the years 2002-2004 and was realized by the filmmaker Laura Waddington, born in 1970 in London. In the first part of this essay, drawing from newspaper articles and individual studies, I will attempt to grasp more precisely and to reconstruct in its main features the referential reality-the setting and the history-in which Border takes place and to which, as a documentary film, Border refers, in order in the further course of the text, to assess how and to what extent the video itself tells of this reality in a specific way. At the center is the question of how the filmmaker approaches this complex reality, in which way and with which filmic forms she gives this reality expression.

At the beginning of the film, an inscription stating the following: "This is a film about Afghan and Iraqi refugees I met in the fields around the Sangatte Red Cross camp, in France. Unable to get to England legally, they tried to enter the channel tunnel, hidden in trucks and on freight trains."

Sangatte is a small town in northern France, right on the sea, a few kilometers south of Calais. It is 35 kilometers from here to England-in clear weather, the coast is visible. Near to Sangatte is the entrance to the fifty-kilometer railway tunnel that runs underneath the English Channel and connects the continent of Europe with Great Britain. Between the coasts pass shuttle trains-rail loops at the terminals enable them to turn around. The trains carry automobiles in double-story, closed cars, and trucks on beds secured with caging. Coming from Brussels on the A16, and from Paris/Dijon on the A26, the trucks can drive over a ramp directly into the terminal compound. In addition to freight trains, around thirty Eurostar high-speed passenger trains commute back and forth each day. The ferry port of Calais also does a brisk business, with more than sixty daily crossings to Dover. ${ }^{1}$

At the time of the war in Yugoslavia, many Albanians from Kosovo came as refugees to the region in order to attempt illegalized entry into Great Britain - since they were denied a permanent migration. They slept in the public spaces of Calais, and local and private aid organizations made provisions for the refugees and demonstrated to the authorities against their living conditions. At the end of September, 1999, the French Ministry of Social Services impounded an empty warehouse on the outskirts of Sangatte and commissioned the Red Cross to install and maintain an emergency shelter there. Originally intended as temporary accommodation for 650 people, the warehouse at Sangatte became the largest refugee camp in France. At the time of its closure in December, 2002, 1,600 people were camping there on a daily basis. Since its opening, more than 70,000 people had stayed there. ${ }^{2}$

1 | See Fezer et al. 2003, p. 9-12.

2 | See Fezer et al. 2003, p. 3-5; “Le centre d'hebergement de Sangatte." 2002; Dufour 2002. 
The following arrivals were increasingly Afghans, Iraqis, and Iraqi Kurds, mostly young men between 16 and 28 years old. For a small portion of the refugees, England was the first destination of their journey; for the majority, it was the last hope. Before setting out on their migration, many had only a vague notion of Europe, and knew little or nothing about asylum procedures and residence permits in the different countries. England was generally made into an Eldorado while on the road-through constantly shifting the place where sights were set, and through communication with other refugees and government workers who said they should "try it over there". In fact, at that time, access to the asylum process was less bureaucratic in Great Britain, and social services were better there than in France or other European countries. ${ }^{3}$ Often this image was also put forward and promoted by profit-oriented traffickers, who could earn large sums of money from the precarious traverse of the Channel. Especially in the camp, after all the disappointments along the way, the United Kingdom was made into an icon, and collective fantasies - such as that of British hospitality—were formed and cultivated. ${ }^{4}$ Ultimately, the refugees had to keep at it-every night, they had to motivate themselves to make another attempt. And after every failure, the country of their dreams seemed again at "a distance, however close it may be"s.

Each night the refugees attempted to cross the border to England unobserved. The camp served as a base, a service station for the fueling and repair of bodies, and a platform for information exchange. In the evening they would set out, mostly in small groups, heading toward the ferry port and the nearby highway rest areas. There, they would attempt to climb unobserved onto a truck bed, or else they would have a "blind date" with a driver, arranged by a smuggler in exchange for a lot of money. However, since the end of 2001, the Eurotunnel terminal was increasingly the objective, where the fugitives would attempt to get directly onto the trains. The main reason for this shift was the massive increase in stringency of truck inspections. Using infrared scanners, X-Ray machines, $\mathrm{CO}_{2}$ monitoring stations, and heartbeat detectors, the clients' cargo was to be made more transparent. ${ }^{6}$

It was five kilometers from the refugee camp to the compound of the Eurotunnel terminal. In between lay the highway A16, which was to be crossed on foot. The compound, equipped with video surveillance and lit to be as bright as day at all hours, is surrounded by multiple wire or barbed-wire fences, up to four meters tall. Then as now, people searched for pre-existing holes in the fencing, cut their own, or attempted to get past the fences by climbing over them. Once the outer security systems had been dealt with, refugees attempted to climb aboard shuttle trains turn-

3 | See Dufour 2002.

4 | See Laacher 2002, p. 101-105.

5 | I am borrowing this phrasing from Benjamin 1968, p. 222.

6 | See Fezer et al. 2003, p. 10-14; “Der Kanaltunnel als Weg illegaler Migration” 2001. 
ing around in the terminal. Occasionally, they jumped from overpasses onto the roofs of approaching trains. Since the high-speed trains produce a high wind pressure, it is not possible to walk through the tunnel on foot. Nevertheless, such attempts have repeatedly been made.?

Although security measures became more and more stringent, hurdles became higher and every attempt more dangerous, the refugees persevered. Stubbornly, tirelessly, evening after evening they set out under cover of darkness, and generally were apprehended on their route. With flashlights, they were taken from the fields and bushes, or were plucked from the trains and brought by the CRS back to the camp at Sangatte. After a failed attempt, many proceeded voluntarily to the buses-"police taxis," as the refugees called them. The attempt to escape became a nightly routine. It was a job-a mission. Giving up would mean making the entire way here into something futile, counting as lost all the hard-earned money invested in smugglers, burying one's own hopes and above all disappointing one's family. ${ }^{8}$

In fact, several people continued to make it somehow, to find their way through somewhere-hurrying with a fleeting shadow, keeping within the blind spot of a border guard, balancing in the off-zone of the surveillance cameras, making use of a technical malfunction or the blinking of the $300-$ eyed security force in the security command center. At the end of 2002, about ten people were successful each night. According to Red Cross estimates, in the three years between the opening and the closing of the camp, of the 60,000 camp residents, $85 \%$ succeeded in reaching England. ${ }^{9}$

In May 2002, Nicolas Sarkozy was named Interior Minister of France, and in solidarity with his British counterpart, the like-minded hardliner David Blunkett, a "new era of cooperation" began, an "energetic, joint course of action against illegal migration across the Channel"10. On November 5 , ten days before the officially announced deadline, the camp was closed to new arrivals. Police officers in front of the building turned away unregistered refugees. ${ }^{11}$ In December 2002, France and Great Britain came to an agreement on the terms of the camp's closing-by the end of the year it was to be entirely vacated. On December 30 , the building was torn down, razed to the ground by bulldozers, and by mid-February, clean-up operations had been concluded. The problem was solved; Sarkozy's coup had been achieved. ${ }^{12}$ Or so it seemed: "When I came back two days later, no trace remained. They left no memory, not even a sign or statue."13

7 | Hahn 2001; "Vierundvierzig Asylsuchende im Kanaltunnel festgenommen" 2001.

8 | See Zappi 2002; Pereira 2001.

9 | See "Fermeture du centre de Sangatte" 2002.

10 | See Ceaux 2002.

11 | See Mesureur 2002.

12 | See Fezer et al. 2003, p. 9-12.

13 | Waddington 2005. 
But the spirits of Sangatte could not be driven away so easily. Winter 2006-three years later: "Des centaines de clandestins errant dans le froid, sans droits, sans protection. L'Etat ne peut continuer à ignorer cette détresse. ${ }^{14}$ The image of the Eldorado England was still twinkling on the horizon, appearing as a fata morgana on the long way here, glittering in the dawn or shimmering in the evening mist, gleaming off the cold coast of France.

This is my attempt at a brief overview of the geographic and political reality in which the video Border was made, and to which Laura Waddington's documentary essay makes reference. Actually, the material has all the makings of a film - it has the components of a plot with suspense and emotion. It provides the context for various possible scenarios and individual dramas. Heroes and villains are given-the roles can be cast differently according to narrative point of view and intended message. The respective motivations, the drive to action, as well as the goals and obstacles are evident: some want to get to England in order to install themselves in a safe country, while others want to preserve their peace and possessions, and take measures accordingly — these elements would be established in the classic first act, the introduction.

An escalation of the conflict, the most important feature of the second act, takes place against the background of an increase in new arrivals, a heightening of security measures and more vigorous deterrence of border crossing, with increasing tension on the political level. There are scenes of action, such as police officers chasing refugees, with figures scaling high fences and leaping onto arriving trains, as well as suspenseful breaks in action - a refugee waits in the dark corner of a truck container while the unsuspecting driver returns from his picnic dinner, or brings his vehicle to the $\mathrm{CO}_{2}$ monitoring station-energetic discussions between politicians and business leaders of the Eurotunnel Corporation, and so forth.

Finally, in the third act there must be a decision that puts an end to the turmoil. This could coincide with the closing of the camp: a happy ending for an Afghani family, who, after staying in the camp for six months, on December 5, 2002 are officially permitted to enter England.15 Or, an unresolved ending for a Kurdish boy, who, one month previously, on November 5, after a year-long migration, is the first one to stand in front of the closed doors of the camp, and who finally, after a violent exchange with the police, constructs a hut in a park in Calais.

The material offers clichés such as good guys and bad guys, the impoverished victims and the ignorant rich people, the blasé, jaded politicians, who, at their meeting tables over a glass of Vittel, make decisions that determine countless fates.

14 | Jeanson/Laacher 2006.

15 | See Zappi 2002; “Grossbritannien nimmt 1000 Kurden auf” 2002.

Bereitgestellt von | Universitaetsbibliothek Basel 
Laura Waddington's video is something else entirely: plot, suspense, emotion are indeed elements, but it is necessary to define these terms specifically for our context.

In September, 2001, the filmmaker visited the region and the refugee camp for the first time, and decided not to film inside the camp. Instead, she went undercover with her digital camera, into the fields and streets between the camp and the Eurotunnel terminal, and took part in the nightly routes and routines of her protagonists. She hid from the police with them in the fields and accompanied their tireless attempts to become stowaways and smuggle themselves across the border.

Figure 2 and 3


Laura Waddington risked adverse conditions and brought her physical situation, her point of view and her mode of existence, close to that of her protagonists. She accompanied their nightly campaigns and attended their barely visible existence as a type of floating consciousness. She became Bereitgestellt von | Universitaetsbibliothek Basel 
"interested" in the most literal sense-she was there, she became an intermediary and transformed the political event into a personal experience.

No establishing shot explains the site to us at the beginning, nor between the takes, establishes a context that would enable us to orient ourselves in the fields. No field commander surveys the situation. We are in the midst of the action with the filmmaker and the protagonists - at night, often in high grass. Together with her and her video camera, our seeing goes to the border. Most of the time, we see little or nothing. If there is light, it is from cars driving past, the spotlights of helicopters, or the flashlights of police searching for refugees in the fields. No omniscient narrator illuminates the situation, explains to us the politically complex constellation, or establishes the chronological sequence of events, as I attempted to do at the beginning of this essay. Waddington made no summary and constructed no overview. Instead, she left a blurry videographic trace-the trace of an encounter with a disturbing reality, the fragment of an action that she attempted in the fields and streets of Sangatte.

The voice-over does provide information about the object of the images - the filmmaker narrates fragments from the lives and destinies of those she encountered, and also names particular events and key dates. However, this information and these descriptions of the situation are just scattered sporadically, and are not illustrated and confirmed by the images, as is customary in classical expository documentary. Together with the other thoughts, in addition to the music, they form a second trace. And this trace is always the trace of an "I" - not a conventionalized and disembodied voice, like that of the sovereign classical commentator, whose statements are to be accepted simply as facts, but the voice of an affected and compassionate subject.

Figure 4

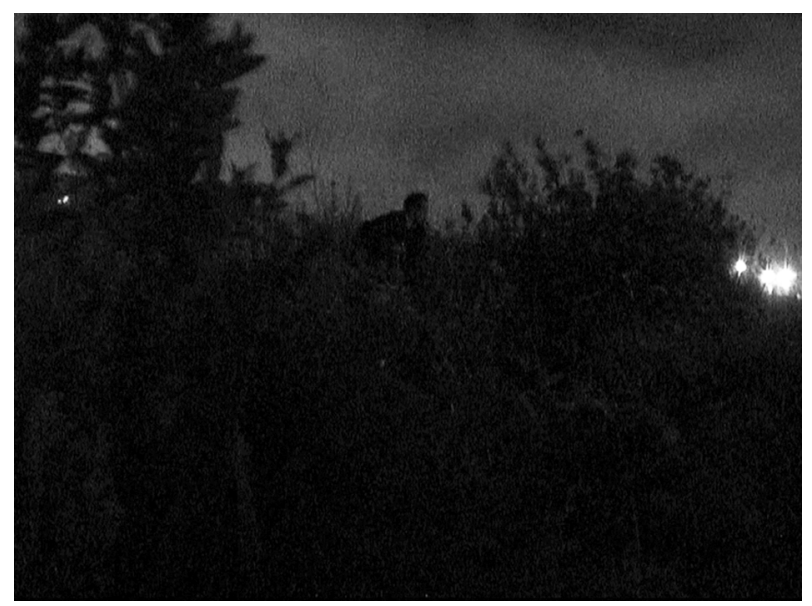

The film Border is shaped by the presence of the filmmaker herself. Laura Waddington does not "document" in the sense of an expository repreBereitgestellt von | Universitaetsbibliothek Basel 
sentation of a profilmic situation, nor does she seek, like a journalistic reporter, to make us able to experience events from the protagonists' perspective. The images are very closely tied to the filmer's line of sight, and her movements and her voice cannot be separated from the filmmaker as a person. The camera's view is not anonymized or objectivized, nor is it identified with the protagonists' view: as much as the filmmaker seeks proximity to her protagonists, and also to an extent does find it, she remains permanently an Other, an outsider, and she reflects herself as such in her images.

Waddington takes part in a life that is not hers and that existentially and socially does not concern her. The boundary space of Sangatte, which functions for the refugees as a space of "enclosing exclusion"16, serves the artist as a type of refuge, where she bides her time in playful existence and artistic production. A free spirit, she accompanies the unfree spirits of Sangatte, which, under the "sovereign ban" ${ }^{17}$, as if in a loop, over and over again make another attempt. What for the fugitives and their pursuers is serious, for her is more like play-ultimately, it is aesthetic play in the sense of a game of hide and seek, in which, despite her physical engagement, she takes on the role of spectator. Because of their different modes of existence, her perspective never coincides with that of her protagonists, and Border deals with this experience of distance in a specific way. The images testify to the aestheticizing, distancing gaze of the filmmaker and her camera, both of which-in attempting to see, to recognize, and to understand-are deflected by the surface of the visible and cast back upon themselves.

But Border is not only the subjective document of a biographical action and experience; it is simultaneously a representative filmic image-a type of sensory allegory-for the disturbing condition in which these semi-transparent, nocturnal shadow beings at the margin of collective consciousness have found themselves. No papers means no identity, no face, underground and without any ground to stand on, restlessly wandering in place. With Border, Laura Waddington creates an image for this barely visible presence, a filmic equivalent for this paradoxical condition of sleepless stasis on the site of transit.

I have termed this filmic image a "memorial" (Denkmal). I mean this in two respects: first, "memorial" in the sense of an appellative "think about this" (Denk-Mal-Nach). Waddington refers to the presence and existence of this pro-filmic reality and wants to bring it to our minds. Second, I mean "memorial" in the performative sense, that the film itself keeps something in mind (Gedenken): this is a film in which thinking, in the sense of reflection as a structure and process, is inherent. In the following, this thesis will be further elaborated.

16 | See Agamben 2002, p. 27.

17 | See Agamben 2002, p. 119.

Bereitgestellt von | Universitaetsbibliothek Basel 


\section{Figure 5}

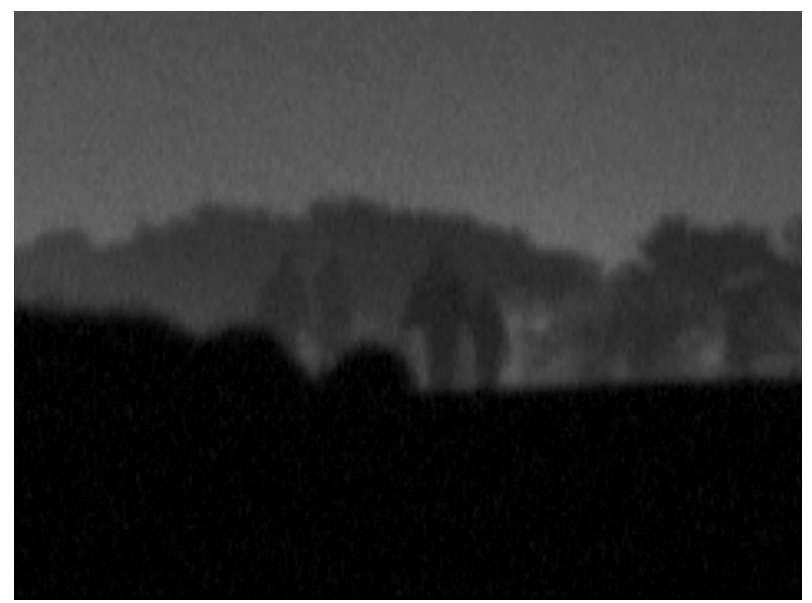

Subjected to the precarious lighting conditions and the unevenness of the terrain, Laura Waddington's camera operates at its technical limits. At the site of the event, it produces artifacts, pictorial disruptions, which obstruct the view of the represented and estrange the concrete, pro-filmic reality. The camera's technical reactions become visible, on one hand in substantial image noise, and on the other hand, in the blurring and stalling of the flow of movement, which has to do with the prolonged exposure time of the individual images. These two effects mark the aesthetic of the video and place the motivic object at an aesthetic distance. The individual takes do not present themselves as objective depictions of a given situation, but rather refer to the endeavors of a technical apparatus, which, consigned to the conditions of the site, is impaired in its functioning and attempts in vain to grasp its object. The faces of the protagonists cannot be identified and their silhouettes remain hazy - they merge with the background into a smoldering noise.

Because of these media-specific disruptions, the referential reality is not seemingly made apparent, but is expressed in the images as a reality that has been transfigured through distortion, that has been apparatively and subjectively mediated. The quasi-subjective reactions of the camera at the site of the action refer to the technicity and opacity of the images, and simultaneously, they contribute to an abstraction of the concrete, to a dissolution of the particular into an approximate, which amounts to a type of un-realization of the real. For a documentary film, this is an astonishing turn.

The filmic image is a witness to its object, without showing this object. Or, showing is here always connected with concealing, and the filmmaker's testament implies the inaccessibility of the visible. For Border evades both our recognizing seeing and our conceptual grasp. We neither recognize concrete or conspicuous details, nor are we carried along by a stringent argumentation or coherent narration. Rather, we are confronted by 
unwieldy and salvaged material—with much that is dark and unexplained, arranged in a fragmentary manner.

This approach testifies to a media-ethical stance: Laura Waddington's protagonists hide in the noise of the image. She protects them from discovery or from visual exposure by the "violent act of the camera" ${ }^{18}$, and she keeps them from being assaulted by a voracious reception. Waddington shows her protagonists confidentially-as secrets. ${ }^{19}$ This runs entirely counter to conventional TV journalism, or even to critically intended documentary films, in which faces often serve as the most important carriers of identification.

At the same time, this approach also testifies to an epistemo-critical stance. In interviews, Laura Waddington talks of being overwhelmed, of the feeling that what she saw in Sangatte could not be communicated, and the constant impression that everything is much more complicated and more complex than people, or than she, is able to understand: "I knew I could only leave a very small and incomplete trace." ${ }^{20}$

As fragmentary as Waddington's work is as a document, as a filmic tableau of a highly unsettling situation, Border comprises an entity, in which these ghostly existences wander restlessly in place. This tableau does not intend to reveal or explain the profilmic reality; rather, it visualizes this reality's presence and existence with genuinely filmic means, and functions as a memorial - a memorial (Denkmal) that aims to meet its own implicit challenge to "think about it" (Denk-Mal-Nach). No utmost and no inmost truth is disclosed. A reality is shown as one that simultaneously conceals itself; a secret is portrayed without being divulged or done away with. Border's drama does not aspire to any resolution-the film remains a tension without any cathartic effect, and in this way Border is a filmic image of the refugees' condition-an intrusive image in which the experience of Sangatte is reflected as defining and traumatic.

I propose reading the artifacts that the camera produces at the site of filming under critical lighting conditions as the traces of a consciousness-first, as the traces of a camera consciousness that accompanies the object being shown. By means of the visible restrictedness of the video gaze and the always concomitantly displayed materiality, the image-producing camera brings itself to mind and the displayed object cannot be separated from the displaying medium. Through the voice-over, which was written later, this camera consciousness receives a personal voice, that of the filmmaker. Through the acoustic memories of the experience in San-

18 | Barthes 1985, p. 102.

19 | In an interview, Laura Waddington says, "I am afraid of filming. For me to film someone is an enormous responsibility because I don't believe a camera just captures the surface but also something underneath. And that's very sensitive and intimate. I think a camera has the potential to be something very violent." Eltimich 2004. 
gatte, the indexical images are brought into a temporal distance and styled as spiritual images that are remembered or recur in dreams. Subjected to the conditions of this location, filmic images are produced that, following Deleuze, can be considered metaphors for mental images. ${ }^{21}$ The technical impairment then symbolizes the deforming processes of time-producing a type of weathered or mentally processed image. The pro-filmic reality is expressed as one that has been internalized and appropriated; or, the videographic expressions take on the quality of subjective impressions, of dream images, of the images of memory.

This effect is enhanced in that Waddington's filmic gestures at the site of the action hardly grasp what they attempt to see and to understand. This is demonstrated in how the camera movements are not subordinated to their object, in the sense of classic "following shots." Instead, the camera movements remain visible as gestures, as actions that are not capable of catching up with their motif. In combination with the almost abstract, dematerialized images, these searching movements become the movements of reflection; they take on the quality of movements of thought. If one considers the conservational aspect of filmic recording, one might conclude that, with the insistent actions of her camera on the site of the event, Waddington anticipates the traumatic memory of this site. She reflects the experience-her own and above all that of the protagonists-in the lastingness of its effect.

In the last third of the film, the descriptions in the course of their recollection in the voice-over revolve around the situation after Sangatte: "Often I thought of that little girl on the road and wondered what she'd remember, where she was now, what she would be." The refugees said to her that later, they would not tell anyone how it had been. "They wanted to forget." Now and then she hears from them; they write to her from Hastings, Margate, Manchester. “They don't like England very much, they thought it would be different." Finally, Waddington directly addresses a specific person. The commentary takes on the form of a letter: "Months later you write me. You told me sometimes walking down the street, it all comes back to you. And you walk all day. And you think maybe you're not strong enough. And the people who live among you they don't know anything."

The radical subjectivity that distinguishes the film Border in many respects is Laura Waddington's artistic answer to the encounter with an extremely complex reality, in which the difference between objective reality and subjective experience, as it is established in the theory of documentary film, becomes untenable. Sangatte is one particular occasion and site in which the harsh reality of facts and the fictive, invented, imaginary merge into one another. Many different stories with varying truth content are condensed at this site-the stories of media, of the refugees, of their smugglers. And the fiction has harsh consequences-ultimately, the pre- 
sentation of a person's life story will determine their entirely real fate, at latest by the time of their application for asylum. The hopes and projections directed at the other side of the Channel, dreams of better lives and local fears are as much a part of the reality of Sangatte as the three daily meals and the Eurotunnel corporation's strengthening of security measures. Sangatte also has a retroactive effect-as a defining and lingering experience, which will leave, which has left impressions and traces.

In Sangatte, a heterogeneous, aggregate condition of reality prevails, and this is the object of Waddington's video reflection. She cuts her narrow trail in the thicket of stories and creates a poem, a filmic commemoration, which brings this repressed parallel world into view in an appropriate way. She treats Sangatte both as the site of muffled fear and delectable hope as well as the site of bitter memory. In retrospect, Sangatte is guarded as a secret, is attempted to be repressed and forgotten. But the experience is haunting. It returns in memories and dreams - this is how Border presents the situation to me.

Translation: Elizabeth Tucker

\section{List OF Figures}

Figures 1-5: filmstills from Border, directed by Laura Waddington, F/GB 2005, $27 \mathrm{~min}$.

\section{BibLIOGRAPHY}

Agamben, Giorgio. 2002. Homo Sacer: Die souveräne Macht und das nackte Leben, Frankfurt am Main: Suhrkamp.

Barthes, Roland. 1985. Die helle Kammer. Frankfurt am Main: Suhrkamp.

Benjamin, Walter. 1969. "The Work of Art in the Age of Mechanical Reproduction.” In Illuminations, ed. Hannah Arendt, p. 217-252. New York: Schocken Books.

Ceaux, Pascal et al. 2002 "M. Sarkozy: 'Il faut porter le fer dans les zones de non-droit'.” Le Monde, May 31.

Deleuze Gilles. 1989. Das Bewegungs-Bild. Frankfurt am Main: Suhrkamp.

Del Lucchese, Filippo. 2005. "The Two Speeds 'Frontera'. Interview with Laura Waddington.” JGCinema, http://www.jgcinema.com/single. php?sl=laura-waddington (accessed July 03, 2010).

"Der Kanaltunnel als Weg illegaler Migration: Britische Besorgnis über französisches Laisser-faire.” 2001. Neue Zürcher Zeitung, September 03.

Dufour, Jean-Paul. 2002."A Sangatte, avec les derniers réfugiés du centre de la Croix-Rouge." Le Monde, December 14.

Dufour, Jean-Paul. 2002. "Le centre d'urgence de Sangatte, une petite ville de 1300 habitants qui rêve d'Angleterre." Le Monde, May 30. 
Eltimich, Cedric. 2004. "Smash The Border. A look at Border. A film disconcerting in its sensitivity." Web Reporters, November 25, http://www. laurawaddington.com/article.php?article $=12$ (accessed august 20, 2006).

"Fermeture du centre de Sangatte." Croix Rouge: Actualités 4e trimestre, December 2002, http://www.croix-rouge.fr/goto/actualites/sangatte/ point-fermeture-2002.asp (accessed september 25, 2006).

Fezer, Jeko et al., eds. 2003. "Grenzgeografie Sangatte." An Architektur 03 (Juli).

"Grossbritannien nimmt 1000 Kurden auf: Rasche Schliessung des Lagers Sangatte bei Calais." 2002. Neue Zürcher Zeitung, December 03.

Hahn, Dorothea. 2001. "Zwischen allen Zäunen." Taz, November 01.

Jeanson, Françoise/Laacher, Smaïn. 2006. "La grande misère de l'après Sangatte." Le Monde, February 24.

Laacher, Smaïn. 2002. Après Sangatte: Nouvelles immigrations, nouveaux enjeux. Paris: La Dispute.

"Le centre d'hebergement de Sangatte au bord de l'explosion." 2002. Le Monde, January 6.

Mesureur, Claire. 2002. "Le centre de Sangatte n'accueille déja plus les nouveaux arrivants." Le Monde, November o7.

Möller, Olaf, 2005. "Interview with Laura Waddington." The 51st Pesaro International Film Festival Catalogue, http://www.laurawaddington.com/ article.php?article=10, (accessed June 27, 2010).

Pereira, Acacio. 2001. "A Sangatte, des migrants prêts à tout essayer pour gagner l'Angleterre." Le Monde, December 29.

"Vierundvierzig Asylsuchende im Kanaltunnel festgenommen." 2001. Neue Zürcher Zeitung, August 31.

Zappi, Sylvia. 2002. "Comment Paris et Londres veulent en finir avec Sangatte." Le Monde, December 03.

Zappi, Silvia. 2002. "Une étude précise les parcours des étrangers de Sangatte." Le Monde, June 14. 
Bereitgestellt von | Universitaetsbibliothek Basel

Angemeldet

Heruntergeladen am | 18.09.18 17:09 